\title{
The Year's at the Spring
}

By Elizabeth Cruickshank

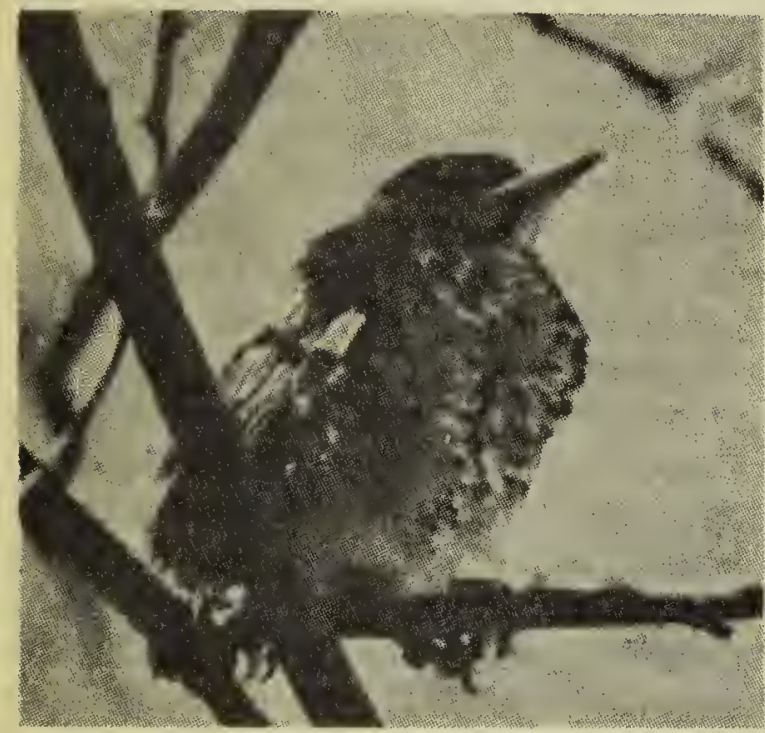

NO sooner was the curtain of winter 1 raised than "Spring came bursting out all over." It seemed as if one day Fogarty and I watched muskrats swim frantically among ice chunks as their creekside houses were flooded; the next redwings were flinging their "okeree" from the rushes and before Fogey had time to investigate the new fresh earth smells, musineon and prairie bean, little crusaders in golden fleece, had taken possession of the golf course hillside. All at once our walks were studded with new interests. Nothing surpassed in beauty dividends our daily pilgrimages to a crabapple orchard of three old trees. To see them early or late or to stand beneath them and look up into the heart of them, with sunbeams sifting through the delicate petals that covered the countless twigs on the manyforked branches-was enough to make the heart ache with the wonder of it.

Our first drive to Lumsden found the valley lapped in peace. A mist of white was on the trees, dull gold and brown, with a tinge of blue in the green of the patchwork fields highlighted by patches of lavender and gold.

The flowers haa answered Judy's roll-call for the procession of Spring as she remembered it. Each had received a loving welcome. As she examined every new shoot of fresh green for the burden of flowers it should bear she fell on her knees beside a little green rosette with its tiny white blossoms: "Dear little Androsace, I knew you would come with the Onions"

The ground felt so friendly to our step, the wind from the west had a clean washed smell when we reached the hilltop to look down on what was in former years the perfect nursery, sheltered by tule and willow, for young bittern. This year it was a lake where grebes, ducks and mudhens were cavorting merrily. We rested in the shelter of the old ash tree in the pasture, by a knoll jewelled with early blue violets. The moss by the trunk, rich brown when last we saw it, was now a lush green cushion covered with brown stems bearing their spore cases aloft, but which the sun made shining copper columns with green flags at their summits. Again the sun made us pause that day as it shone through a robin's yellow bill, making it appear transparent, fragile, quite different from the opaque yellow bill of the starling, yet not so exciting as the vivid pink bill in the black face of the Harris Sparrow.

The slow buzzing of the clay-coloured sparrow came from the cherry tree as if to accompany the cheerful note of the yellow warbler in the saskatoon bushes. A wren added his spring song as he flitted busily from tree to tree. A robin joined the choir from the hawthorn tree as the rich whistle of the oriole came from the top of the cottonwood. Judy heard singing too from an old flicker's nest. We investigated to find a nestful of wee pink mice, on a cozy bed of cowhair.

What pleasure there is in common things! In spring the tempo of our joy is quickened of course, from the moment. when we are wakened by a sing like a tinkling bell caressing the early morning air till the evening's purple glow brings the robin's plaintive note and my Te Deum "I thank Thee that I love the things of earth." For before our eyes in spring unfolds:

"An opulence beyond the dream of kings

After the frugal winter and its cold

Not for the hands, but for the heart to hold." 